\title{
Prognostic factors of 30-days mortality in primary intracerebral hemorrhage
}

\author{
S Tsikriki , A Karathanou, I Kokoris, T Topalis, E Voutsinas, A Antoniou, E Choli, S Pamouki \\ From ESICM LIVES 2015 \\ Berlin, Germany. 3-7 October 2015
}

\section{Introduction}

Spontaneous intracerebral hemorrhage $(\mathrm{ICH})$ carries a high mortality rate and predictive factors of shortterm outcome are of great importance. Studies have shown that image volumetric evaluation of hematoma, in the initial computed-tomography (CT-scan) of the brain, has an important predictive value of 30-days mortality.

\section{Objectives}

To review patients (pts) with $\mathrm{ICH}$, in a five-year period (January 2010-December 2014) and to assess the predictors of 30-days mortality. As the biggest diameter accounts to the calculation of the hematoma blood volume, we examined a possible association between this diameter and early fatal outcome.

\section{Methods}

Retrospective analysis of 30-days mortality in 62 pts (49 male,13 female, mean age $65,74 \pm 11,18$ ) hospitalized in our ICU. Age, Apache II score, Sofa score and GCS were recorded on admission day. CT-scan was performed in order to determine the site of the $\mathrm{ICH}$, the presence of intraventricular hemorrhage (IVH) and the amount of $\mathrm{ICH}$. Volume was estimated using the $\mathrm{ABC} / 2$ method and the biggest diameter was recorded separately. Statistical analysis was performed by using SPSS V-20 soft-ware. Variables were described using mean and SD (continues variables) or category percentages (categorical variables), stratified for survivors and nonsurvivors. Independent Samples t-test for Equality of Means, Shapiro-Wilk test of Normality, Pearson correlation and Pearson ChiSquare test were used and level of significance was set at $\mathrm{p}<0,05$.

\section{Results}

38 pts (group I) nonsurvived in the ICU during the first month and 24 pts (group II) survived and discharged from acute hospitalization. The overall mortality was 61,29\%.See results in table 1.

Biggest diameter of hematoma and $\mathrm{ICH}$ volume have a positive linear correlation (Pearson correlation $R^{2}=$ 0,664 ). Furthermore, we attempted to establish a possible association between the $\mathrm{BD}$ and the 30-days mortality. We divided our pts in: Group A (12 pts):BD $\leq 4 \mathrm{~cm}$ and Group B (50pts): BD $>4 \mathrm{~cm}$. One patient died in group A $(8,3 \%)$, while 37 pts died in group B (74\%) (Pearson Chi-square test $\mathrm{p}<0,0001$, odds ratio:0,032).

\section{Conclusions}

We demonstrated that Apache II score,Sofa score, GCS on admittion and $\mathrm{ICH}$ volume are independent predictive factors of 30-days mortality in pts with $\mathrm{ICH}$. The size of the biggest diameter (cut off $4 \mathrm{~cm}$ ) has a strong association with the 30 -days mortality, thereby it could be an independent predictive factor in these group of patients.

Table 1

\begin{tabular}{llll}
\hline & Group I & Group II & p value \\
\hline Age & $65,97 \pm 11,57$ & $65,38 \pm 10,76$ & $\mathrm{p}=0,8$ \\
\hline Apache II score & $23,13 \pm 5,60$ & $15,63 \pm 6,14$ & $\mathrm{p}<0,0001$ \\
\hline Sofa score & $9,16 \pm 2,66$ & $5,96 \pm 2,56$ & $\mathrm{p}<0,0001$ \\
\hline GCS & $4,76 \pm 1,79$ & $8,79 \pm 3,09$ & $\mathrm{p}<0,0001$ \\
\hline ICH volume (cm3) & $62,68 \pm 23,20$ & $27,42 \pm 23,22$ & $\mathrm{p}<0,0001$ \\
\hline biggest diameter (BD) (cm) & $6,9 \pm 1,26$ & $4,58 \pm 1,60$ & $\mathrm{p}<0,0001$ \\
\hline [Comparison of 30-days mortality] & &
\end{tabular}




\section{References}

1. Szepesi Rita, Szell Katalin Ibolya, Csiba Laszlo: New Prognostic Score for the Prediction of 30-day outcome in Spontaneous Supratentorial Cerebral Haemorrhage. Biomed Research International Volume 2015 [http:// http:dx.doi.org/10.1155/2015/961085].

2. Claude Hemphill J, Bonovich David, Tuhrim Stanley: The ICH score: A simple, reliable grading scale for Intracerebral Hemorrhage Stroke 2001, 32:891-897.

doi:10.1186/2197-425X-3-S1-A983

Cite this article as: Tsikriki et al: Prognostic factors of 30-days mortality in primary intracerebral hemorrhage. Intensive Care Medicine Experimental 2015 3(Suppl 1):A983.

\section{Submit your manuscript to a SpringerOpen ${ }^{\circ}$ journal and benefit from:}

- Convenient online submission

- Rigorous peer review

- Immediate publication on acceptance

- Open access: articles freely available online

- High visibility within the field

- Retaining the copyright to your article

Submit your next manuscript at $\gg$ springeropen.com 